\title{
DETERMINATION OF HYDROGEN CONCENTRATION INFLUENCE ON STRESSES IN STRUCTURES
}

\author{
Mykola Stashchuk $^{1}$; Vasyl Boiko ${ }^{1}$; Roman Hromyak ${ }^{2}$
}

\author{
${ }^{1}$ Karpenko Physico-Mechanical Institute of the National Academy of Sciences of \\ Ukraine, Lviv, Ukraine \\ ${ }^{2}$ Ternopil Ivan Puluj National Technical University, Ternopil, Ukraine
}

\begin{abstract}
Summary. In most cases the metal structures service under operating conditions results in the fact that these structures or their certain elements are constantly affected not only by mechanical factors (load, residual stresses, etc.), but also by the environment. Elements of pipelines, load-bearing sections of thermal and hydroelectric power stations, metal structures of bridges are all influenced by the environment that fills or surrounds them. Such environment depending on the content of acids and alkalis, a number of hydrogencontaining media can be corrosive. It should be also noted that the influence of such corrosive environment and mechanical factors influence are simultaneous and interrelated resulting very often in brittle or quasi-brittle metal fracture. Therefore, the problem of estimating the basic metal structures engineering parameters (strength, reliability, etc.) that are corroded by the simultaneous action of mechanical force factors, is currently an important problem of industrial operation. The problems of hydrogen interaction and stresses in metal structures are still not sufficiently investigated. While hydrogenating the metal body, the linear dimensions of its elements and volume change. At the same time, changing body volume, under certain conditions, causes internal stresses. Let us assume that the interaction between hydrogen atoms is negligible. It is necessary to establish the stress-strain state of the metal body due to the hydrogen concentration in it. Stresses in the body also occur due to external loads $\sigma_{i k}(i, k=1,2,3)$. According to the classical theory of elasticity, stresses of such nature cause the corresponding elongations and displacements. Therefore, stresses $\sigma_{i k}$ cause deformation. According to the superposition law, the increase in total deformations is equal to the sum of deformations caused by the change in the hydrogen concentration and deformations caused by stresses in the body.
\end{abstract}

Key words: stresses, deformation, hydrogen concentration, finite elements method, backward Eulermethod, virtual work principle, cylindrical samples.

Introduction. Hydrogen in metal structures affects their strength and durability. The peculiarity of the hydrogen influence on these properties is its smooth permeability through the lattice and crystalline grating of metal. Hydrogen atoms in metals also cause their crystal lattice expansion [1]. Investigations of hydrogenetation and dehydration of metals indicate the occurrence of hydrogen concentration inhomogeneities [2], which initiates in metals stresses from hydrogen concentration changes. Therefore, taking into account the internal stresses of hydrogen nature is relevant to the development of modern technologies in the structures operating under conditions of interaction with hydrogen-containing environments. It should be noted that such investigations usually undergo unilateral influences of mechanical stress on the distribution of hydrogen concentration [3-6]. At the same time, the improvement of these developments requires detailed investigations of the stress-strain state caused by the change in hydrogen concentration in metals. In [7] the estimation of the stress field cause by diffused hydrogen atoms in metallic continuous cylinder is given. The approach proposed in this paper is generally suitable for estimating the stress field for infinite bodies. In this paper, the method of assessment for the stress field of finite bodies is proposed. 
Initial equations and solution scheme for the problem. When the metal body is hydrogeneted, the linear dimensions of its elements and volume change [2]. Also, changing body volume under certain conditions causes internal stresses. We consider that the interaction betweenhydrogen atomsis negligible. We will establish stress-strain state of the metal body caused by the change in its hydrogen concentration in it.

The complete deformation of the material element when the hydrogen concentration changes on $C_{H}$ value is schematically presented in Fig. 1. It is evident from this figure that the parallelepiped edge

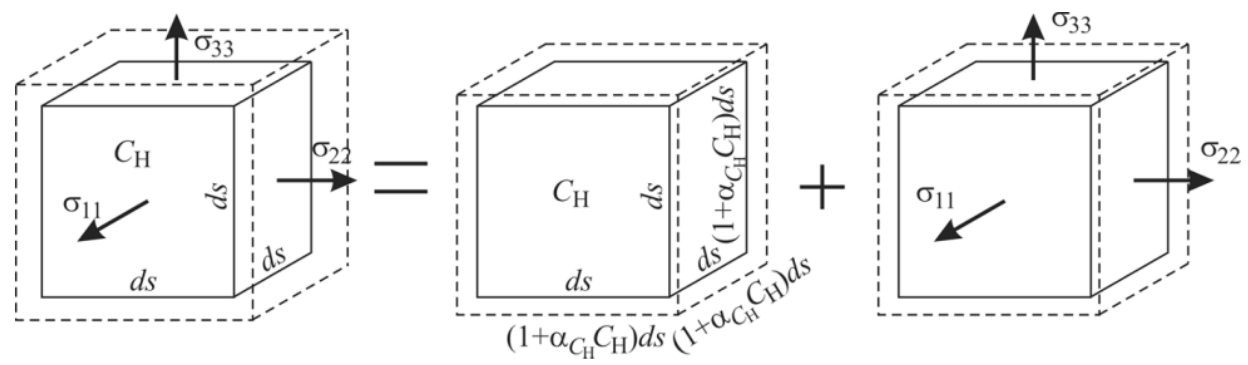

Figure 1. The scheme of complete deformations taking into account hydrogen deformations

Length $d s$ will have new length $\left(1+\alpha_{C_{H}} C_{H}\right) d s$. The parameter $\alpha_{C_{H}}$ is the coefficient of concentration expansion [2]. For isotropic homogeneous body $\alpha_{C_{H}}$, it does not depend on the element $d s$ direction. If we also assume that $\alpha_{C_{H}}$ is independent on the concentration, then it will be constant. In this case, the initial infinite small rectangular parallelepiped remains rectangular. That is, the elongation in all directions will have the same meaning. The hydrogen concentration on value $C_{H}$ during period of time $\Delta \mathrm{t}$ will result in the increase of further hydrogen deformations.

$$
\Delta \varepsilon_{i j}^{H}=\alpha_{C_{H}} C_{H}=\alpha_{C_{H}}[C(t+\Delta t)-C(t)], i, j=1,2,3 ; \varepsilon_{i j}^{H}=0 \text { при } i \neq j .
$$

According to the superposition law the growth of complete deformations is equal to the sum of deformation growth caused by hydrogen concentrations and deformations caused by external loads

$$
\Delta \varepsilon_{i j}=\Delta \varepsilon_{i j}^{P}+\Delta \varepsilon_{i j}^{H}
$$

The distribution of hydrogen concentrations in the material we will calculate on the basis of Fick equation solution which takes into account the influence of mechanical stress gradient on hydrogen diffusion [4-6]:

$$
\frac{\partial C}{\partial t}=\nabla(D \nabla C)+\nabla\left(\frac{D V_{\mathrm{H}}}{R T} \nabla \sigma_{\mathrm{h}}\right)
$$

where $\nabla=(\partial / \partial \mathrm{x}, \partial / \partial \mathrm{y}, \partial / \partial z)$ is Hamilton operator Гамільтона; $D$ is diffusion coefficient; $R$ is universal gas constant; $T$ is absolute temperature; $V_{H}$ is partial molar volume of hydrogen in metal; $\sigma_{\mathrm{h}}$ is hydrostatic component of the stress tensor in metal; $t$ is time.

Equation (3) is solved under the following initial conditions 


$$
\left.C(x, y, z, t)\right|_{t=0}=C_{0},
$$

On the surface part $S_{c}$ we define the value of hydrogen concentration $\mathrm{C}_{c}$, and on the other part - the hydrogen flow $\varphi$. In this case $S_{c} \cup S_{N}=S$.

Algorithm for calculation the stresses caused by hydrogen concentration. It is practically impossible to obtain the closed solution of equation (3) that is why for its solution we use the finite element method. For this, we divide the investigated body into $n$ finite elements. Solution of equation (3) is found in the form of certain basic functions $N_{i}$ expansion:

$$
C(x, y, z, t)=\sum_{i=1}^{m} N_{i}(x, y, z) C_{i}(t)=[N]^{\mathrm{T}}[C]
$$

where $N_{i}$ is form functions [8]; $m$ is the number of element nodes; $C_{i}(t)$ is hydrogen concentration value value in the $i$-th node of finite element. That is

$$
[N]^{\mathrm{T}}=\left[N_{1} N_{2} \ldots N_{m}\right],[C]^{\mathrm{T}}=\left[C_{1} C_{2} \ldots C_{m}\right] .
$$

After recording hydrogen concentration in the form of (5) and simple mathematical transformations we receive finite element equation for calculation of hydrogen concentration in finite elements nodes:

$$
[M]\left[\frac{\partial C}{\partial t}\right]+\left[K_{H}\right][C]=[F]
$$

where $[M]$ and $\left[K_{H}\right]$ are relatively are the global matrices of concentration and diffusivity; $[F]$ is the vector of diffusion flow.

It should be noted that matrices $[M],\left[K_{H}\right]$ and vector $[F]$ are calculated on the basis of the same matrix for each element of the investigated body. They can be calculated according to the ratios

$$
\begin{aligned}
& {\left[M^{e}\right]=\iint_{V^{(e)}}[N]^{\mathrm{T}}[N] d V,\left[K_{H}^{e}\right]=\left[K_{1}^{e}\right]+\left[K_{2}^{e}\right]\left[K_{1}^{e}\right]=D \iiint_{V^{(e)}}[B]^{\mathrm{T}}[B] d V,} \\
& {\left[K_{2}^{e}\right]=-\frac{D V_{h}}{R T} \iiint_{V^{(e)}}[B]^{\mathrm{T}}[B]\left[\sigma_{h}\right][N] d V,\left[F^{e}\right]=-\oint_{S_{N}^{(e)}}[N]^{\mathrm{T}} \Phi d S,}
\end{aligned}
$$

where $V^{(e)}$ is the element volume; $S_{N}^{(e)}$ is the element surface through which the hydrogen flow passes; $[B]$ is differentiation matrix $[8] ;\left[\sigma_{h}\right]$ is vector containing the values of hydrostatic stresses at the element nodes.

Let us present equation (7) in the following way

$$
[M]\left[\frac{\partial C}{\partial t}\right]+\left[K_{1}\right][C]=[F]-\left[K_{2}\right][C]
$$


where matrices $\left[K_{1}\right] \mathrm{i}\left[K_{2}\right]$ are composed on the basis of corresponding matrices for elements $\left[K_{1}^{e}\right]$ and $\left[K_{2}^{e}\right]$.

Following paper [8], equation (9) is as follows

$$
\left[\begin{array}{ll}
M_{c c} & M_{c a} \\
M_{a c} & M_{a a}
\end{array}\right]\left[\begin{array}{l}
\partial C_{c} / \partial t \\
\partial C_{a} / \partial t
\end{array}\right]+\left[\begin{array}{ll}
K_{1 c c} & K_{1 c a} \\
K_{1 a c} & K_{1 a a}
\end{array}\right]\left[\begin{array}{l}
C_{c} \\
C_{a}
\end{array}\right]=\left[\begin{array}{l}
F_{c} \\
F_{a}
\end{array}\right]-\left[\begin{array}{ll}
K_{2 c c} & K_{2 c a} \\
K_{2 a c} & K_{2 a a}
\end{array}\right]\left[\begin{array}{l}
C_{c} \\
C_{a}
\end{array}\right],
$$

where index «c» is associated with known concentrations and (or temperatures) and index «a» is unknown. If we assume that values $C_{c}$ do not depend on time, then the unknown values of hydrogen concentration $C_{a}$ (in further calculation index «a» is neglected) can be found from the following equation.

$$
\left[M_{a a}\right]\left[\frac{\partial C}{\partial t}\right]+\left[K_{1 a a}\right][C]=\left[F_{a}\right]-\left[K_{1 a c}\right]\left[C_{c}\right]-\left[K_{2 a c}\right]\left[C_{c}\right]-\left[K_{2 a a}\right][C] .
$$

In order to solve equation (9) let us use backward Euler method [8]. In this case

$$
\left[\frac{\partial C(t)}{\partial t}\right] \cong \frac{[C(t+\Delta t)]-[C(t)]}{\Delta t}=\frac{[C]_{t+\Delta t}-[C]_{t}}{\Delta t} .
$$

We also assume

$$
\left[K_{2 a c}\right]_{t+\Delta t}\left[C_{c}\right]=\left[K_{2 a c}\right]_{t}\left[C_{c}\right],\left[K_{2 a a}\right]_{t+\Delta t}[C]=\left[K_{2 a c}\right]_{t}[C]_{t} .
$$

Taking into account (12) and (13), equation (11) is presented as follows

$$
\left.\left[\frac{\left[M_{a a}\right]}{\Delta t}+\left[K_{a a}\right]\right][C]_{t+\Delta t}=\left[F_{a}\right]+\left(\frac{\left[M_{a a}\right]}{\Delta t}-\left[K_{2 a a}\right]_{t}\right)[C]\right]_{t}-\left(\left[K_{1 a c}\right]+\left[K_{2 a c}\right]_{t}\right)\left[C_{c}\right] .
$$

Equation (14) makes it possible to calculate the value of hydrogen diffusion in the investigated body. At the first step when $t=\Delta t$, knowing the vectors $\left[C_{c}\right],[C]_{t=0},\left[K_{2 a a}\right]_{t=0}$ and $\left[K_{2 a c}\right]_{t=0}$, we can easily calculate the vector. While calculating $\left[K_{2 a a}\right]_{t=0}$ and $\left[K_{2 a c}\right]_{t=0}$ we assume that the hydrostatic stresses at the finite elements nodes are equal to zero. For calculation hydrogen concentration at $t=2 \Delta t, 3 \Delta t, \ldots, l t$ it is necessary to know the values of hydrostatic stress at the nodes at $t=\Delta t, 2 \Delta t, 3 \Delta t, \ldots,(l-1) t$. The hydrostatic stresses will be determined as follows. The principle of virtual work for quasi-static equilibrium equations in the stepwise formulation for time moment $t+\Delta t$ is be represented as [9]

$$
\int_{V} \delta\left([\varepsilon]^{T}\right)^{+\Delta t}[\Delta \sigma] d V=\int_{\Gamma} \delta\left([u]^{T}\right)^{+\Delta t}[\Delta p] d \Gamma+\int_{\Gamma} \delta\left([u]^{T}\right)^{t+\Delta t}\{p\}^{t} d \Gamma-\int_{V} \delta\left([\varepsilon]^{T}\right)^{t+\Delta t}([\sigma])^{t} d V
$$

where $[\Delta \sigma],[\Delta p]$ are relatively the vectors of the growth of Cauchy stresses and surface effort during period of time $\Delta t ; \delta([\varepsilon])^{t+\Delta t}$ and $\delta([u])^{t+\Delta t}$ virtual variables of complete deformation 
and displacement at the moment of time $t+\Delta t ; V$ and $\Gamma$ is body volume and surface, respectively.

In order to solve this problem we use finite element method. Division of the investigated area into finite elements is the same as for equation (14). In this case we divide the integration area $V$ into finite elements. Then the vectors of displacement fields can be presented through the forms function $N_{i}$ and nods displacement vector $[u]$. If we take into account (2), then the stress growth can be calculated in the following way

$$
[\Delta \sigma]=[D][B][\Delta u]-[D]\left[\Delta \varepsilon^{H}\right],
$$

where $[D]$ is elasticity matrix.

In further calculations we assume that vectors $[p]$ and $[\Delta p]$ are equal to zero. After simple transformations and taking into account (16) we get finite element equation for determination $[\Delta u]$ at the moment of time $t+\Delta t$

$$
[K][\Delta u]_{t+\Delta t}=\left[F_{H}\right]_{t+\Delta t}+\left[F_{S}\right]_{t},
$$

where global stiffness matrix $[K]$ and vectors $\left[F_{H}\right]_{t+\Delta t}$ and $\left[F_{S}\right]_{t}$ for the investigated area are calculated on the basis of the same values for the elements

$$
\left[K^{e}\right]=\int_{V^{e}}[B]^{T}[D][B] d V,\left[F_{H}^{e}\right]_{t+\Delta t}=\int_{V^{e}}[B]^{T}[D]\left[\varepsilon^{H}\right]_{t+\Delta t} d V,\left[F_{S}^{e}\right]_{t}=\int_{V^{e}}[B]^{T}[\sigma]_{t} d V .
$$

Having found from (17) $[\Delta u]_{t+\Delta t}$, from (16) it is easy to find $[\Delta \sigma]$. Now for the moment of time $t+\Delta t$ we can write

$$
[\sigma]_{t+\Delta t}=[\sigma]_{t}+[\Delta \sigma]
$$

Using numerical solutions of finite - element equations (14) and (17), stresses caused by the hydrogen concentration in the material at the moment of time $t=\Delta t, 2 \Delta t, 3 \Delta t, \ldots, l t$ can be found.

Testing the method. The use of the proposed method for the calculation of stresses caused by hydrogen concentration change is illustrated by cylindrical samples. Since these problems are axisymmetric, it is sufficient for their solution to solve the problem for the radial cylinder cross section. The first sample is the continuous cylinder with radius $b$ and length $2 h$ (Fig. 2). The cases where it is free from fixing and fixed at one of the endsare concidedred. In case of free from fixing samples we consider only their upper half. Also while calculationing we assume that hydrogen flow is zero. The boundary and initial conditions for the unfixed cylinder are as follows

$$
\begin{aligned}
& C(r, z, 0)=C_{0}, \text { при } 0 \leq r<b, 0 \leq z<h, \\
& C(r, z, t)=C_{c}, \text { при } r=b, 0 \leq z<h, \\
& C(r, z, t)=C_{c}, \text { при } 0 \leq r \leq b, z=h, \\
& u_{z}(r, z, t)=0, \text { при } z=0,0 \leq r \leq b .
\end{aligned}
$$


For fixed cylinder they are the following

$$
\begin{aligned}
& C(r, z, 0)=C_{0}, \text { при } 0 \leq r<b, 0 \leq|z|<h, \\
& C(r, z, t)=C_{c}, \text { при } r=b, 0 \leq|z|<h, \\
& C(r, z, t)=C_{c}, \text { при } 0 \leq r \leq b, z=h, \\
& u_{z}(r, z, t)=u_{r}(r, z, t)=0, \text { при } 0 \leq r \leq b, z=-h .
\end{aligned}
$$

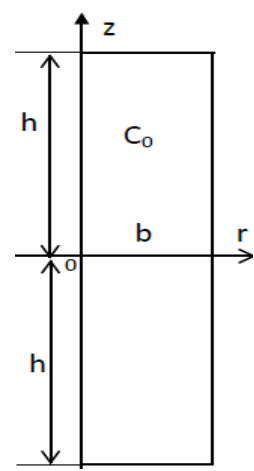

Figure 2. Radial cross section of solid cylinder

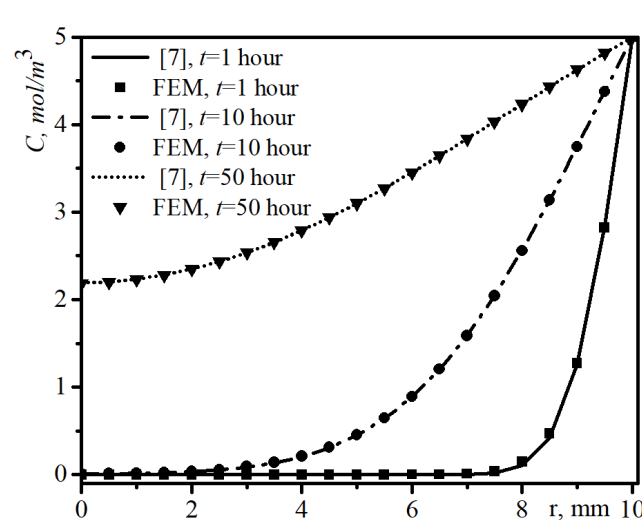

Figure 3. Comparison of the results of numerical and analytical equation (14) solution under long cylinder hydrogenation

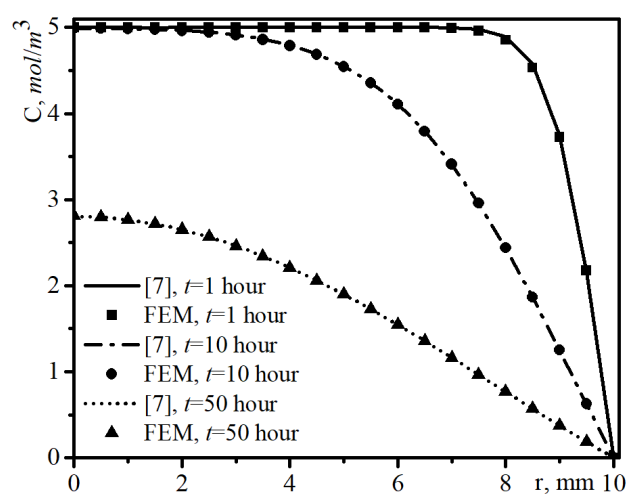

Figure 4. Comparison of the results of numerical and analytical equation (14) solution under long cylinder dehydration

The calculations were carried out for two cases of boundary conditions: hydrogenation $\left(C_{0}=0, C_{c}=5 \mathrm{~mol} / \mathrm{m}^{3}\right)$ and dehydration $\left(C_{0}=5 \mathrm{~mol} / \mathrm{m}^{3}, C_{c}=0\right)$ of the cylinder. Further calculations are carried out with the following parameters: Young modulus $E=2.1 \cdot 10^{5} \mathrm{MPa}$, Poisson coefficient $v=0.3, D=10^{-10} \mathrm{~m}^{2} / \mathrm{s}, \varphi=0, R=8,31 \mathrm{~J} /(\mathrm{mol} \cdot \mathrm{K}), V_{H}=1,96 \cdot 10^{-6} \mathrm{~m}^{3} / \mathrm{mol}$, $T=295 \mathrm{~K}, a=5 \mathrm{~mm}, b=10 \mathrm{~mm}, h=40 \mathrm{~mm}$.

While dividing the investigated area into finite element four nods linear finite elements were used. To solve equations (14) and (17) the software package in FORTRAN algorithmic language was created. It made it possible to find hydrogen concentration change and corresponding stresses growth for arbitrary moment of time. To test the program the closed solution [7] was used during the calculation of hydrogen concentration for long cylinder hydrogenation and dehydration. It is obvious from Fig. 3 and 4, a remarkable convergence is observed between the results obtained by means of program [7].

Equations (14) and (17) were solved with step $\Delta t=1$ minute. In this case the radial cross section of unfixed cylinder was divided into 900 four nodes s elements (966 nodes). Accordingly, for fixed cylinder 1800 elements (1911 nodes). The calculations were carried out for both hydrogenation and dehydration. Analysis of the obtained results showed that during hydrogenation and dehydration of solid fixed and unfixed cylinders the stresses are equal according to their absolute value and differs only in sign. This is confirmed by the results presented in Figure 3 and 4. Therefore while considering further the results obtained, we will deal omly with the results for dehydration. 


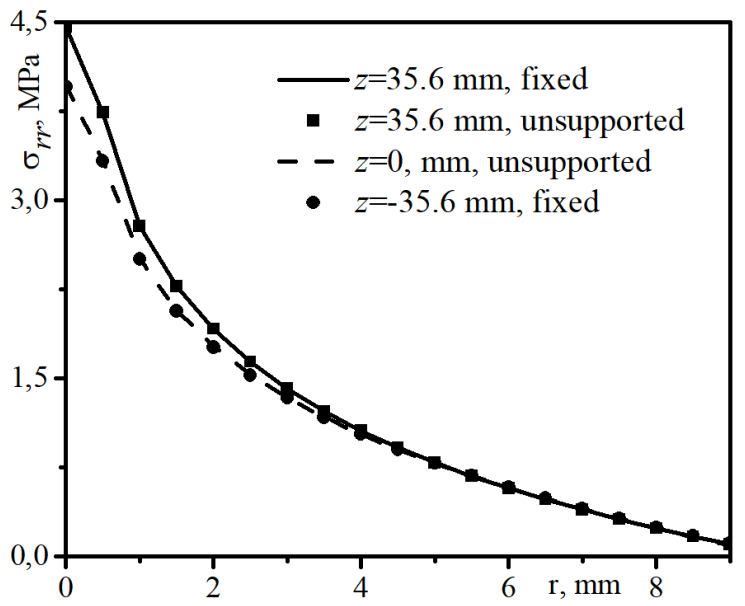

Figure 5. The character of stress distribution $\sigma_{r r}$ for different $z$ of fixed and unfixed solid cylinders at $t=100 \mathrm{~h}$

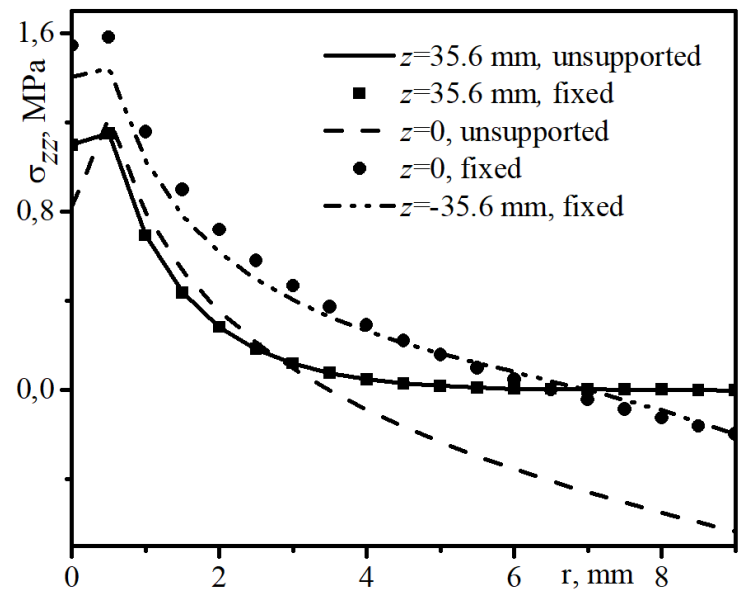

Figure 6. The character of stress distribution $\sigma_{z z}$ for different $z$ of fixed and unfixed solid cylinders at $t=100 \mathrm{~h}$

Figure 5 shows the character of stress distribution $\sigma_{r r}$ for cross sections at different $z$ of both fixed and unfixed cylinders. Results presented in this figure indicate that the stress value and behaviuor do not depend on $z$ value and are the same for fixed and unfixed cylinders. Analysis of the obtained digital results confirms the same behavior of the stresses $\sigma_{\varphi \varphi}$. Although in the case of $\sigma_{z z}$ stresses (Fig. 5) such coincidence is not observed.

Similar calculations were carried out for the cylinder with the groove located in the middle of its cross section (Fig. 7). In this case, $R=2.5 \mathrm{~mm}$. The boundary and initial conditions for the cylinder with the groove are as follows

$$
\begin{aligned}
& C(r, z, 0)=C_{0}, \text { при } 0 \leq r<a+R-\sqrt{R^{2}-z^{2}}, 0 \leq z<R, \\
& C(r, z, 0)=C_{0}, \text { при } 0 \leq r<b, R \leq z<h, \\
& C(r, z, t)=C_{c}, \text { при } r=a+R-\sqrt{R^{2}-z^{2}}, 0 \leq z<R, \\
& C(r, z, t)=C_{c} \text {, при } a+R<r<b, z=R, \\
& C(r, z, t)=C_{c}, \text { при } r=b, R<z<h, \\
& C(r, z, t)=C_{c}, \text { при } 0 \leq r \leq b, z=h, \\
& u_{z}(r, z, t)=0, \text { при } z=0,0 \leq r \leq b .
\end{aligned}
$$

For the fixed cylinder at the end $z=-h$, the boundary and initial conditions for the diffusion equation for the lower cylinder part are the same as for the upper one. Only in this case the value $C_{c}$ is not set at the lower end $z=-h$. For displacements, the boundary conditions are similar to those of the fixed solid cylinder (21). The unfixed cylinder was divided into 1022 four-node elements (1098 nodes) and fixed one into 2058 elements (2186 nodes). Step in time is $\Delta t=1$ minute. 


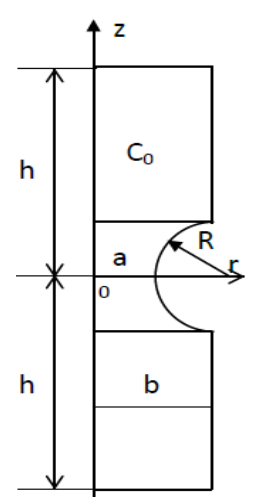

Figure 7. Radial cross section of the cylinder with groove in the middle

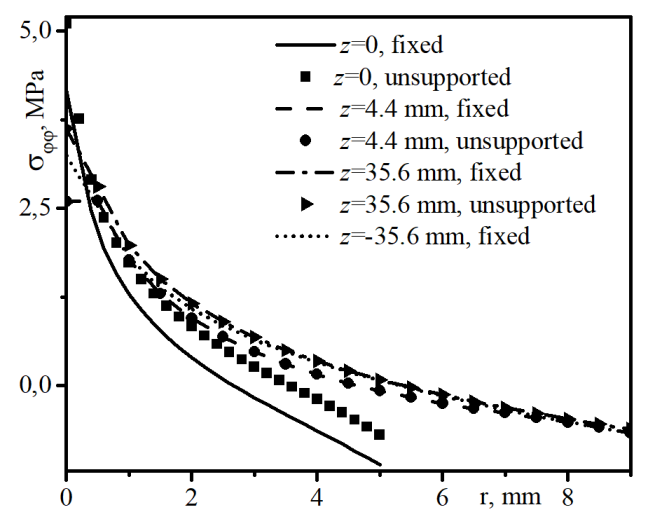

Figure 8. Comparison of stress changes $\sigma_{\varphi \varphi}$ for different $z$ of the fixed and unfixed cylinder with the groove at $t=100 \mathrm{~h}$

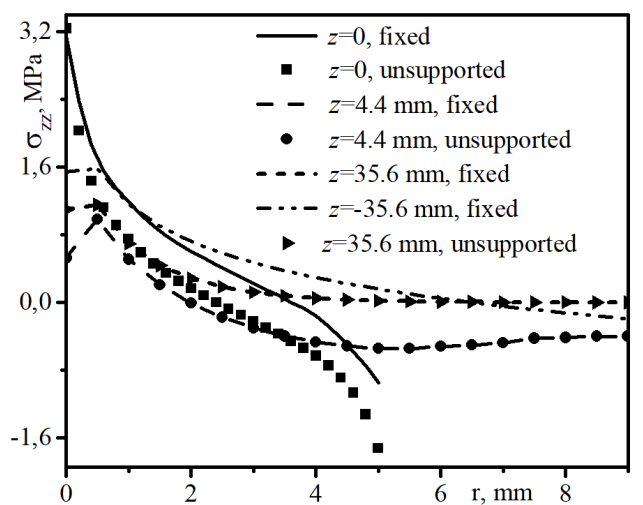

Figure 9. Comparison of stress changes $\sigma_{z z}$ for different $z$ of the fixed and unfixed cylinder with the groove at $t=100 \mathrm{~h}$

Analyzing the graphical data presented in Fig. 8, we can conclude that as in the previous case, the stresses distribution of $\sigma_{\varphi \varphi}$ at $|z|>R$ are almost the same for both fixed and unfixed cylinders with grooves, herein they practically the same in value for all $z$ in this range. On the contrary, at $|z|<R$ these stresses depend significantly on the fact if the cylinder is fixed or not.

For these $z$ they differ from stresses for $|z|>R$. This is probably due to the fact that at this point the radius of the cylinder is smaller than the radius for other $z$ and dehydration here is faster. Analysis of the obtained digital data shows that the behavior of the stresses $\sigma_{r r}$ for both fixed and unfixed cylinders with groove completely coincides with the behavior of the same stresses for the cylinder without the groove. That is, for all $z$ they are the same both fixed and unfixed cylinders. The character of the stress distribution $\sigma_{z z}$ (Fig. 9) at $z>R$ is practically the same for both both fixed and unfixed cylinders with grooves. For all other $z$, these stresses significantly depend on the fact if the cylinder is fixed.

Similar calculations were carried out for the cylinder in which the groove was not symmetrically located to its middle (Fig. 10). It was assumed that the lower end of the cylinder was rigidly fixed at the lower end $z=-h_{1}$. In this case $h_{1}=9 \mathrm{~mm}$. All other dimensions were the same as for symmetric cylinder. The boundary and initial conditions are similar to the same conditions for symmetrical fixed cylinder with the groove. The radial cross section of the cylinder was divided into 1378 (1472 nodes) four nodes linear elements. Step in time is $\Delta t=1$ minute.

From the analysis of Fig. 11 Iit can be concluded, that the change character in stress $\sigma_{\varphi \varphi}$ for cross sections at all $z$ of both symmetric and asymmetric fixed cylinders with grooves are almost identical. If we analyse the obtained numerical data, then comparing the change character of stresses $\sigma_{r r}$ it will be also the same for all cross sections. Also there is equality of stresses $\sigma_{z z}$ almost at all $z$ for symmetric and asymmetric cases (Fig. 12). Exceptions are cross sections neighboring the fixing. 


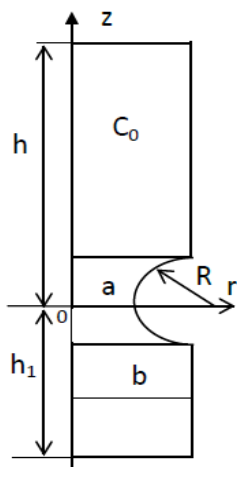

Figure 10. Radial cross section of the asymmetric cylinder with groove

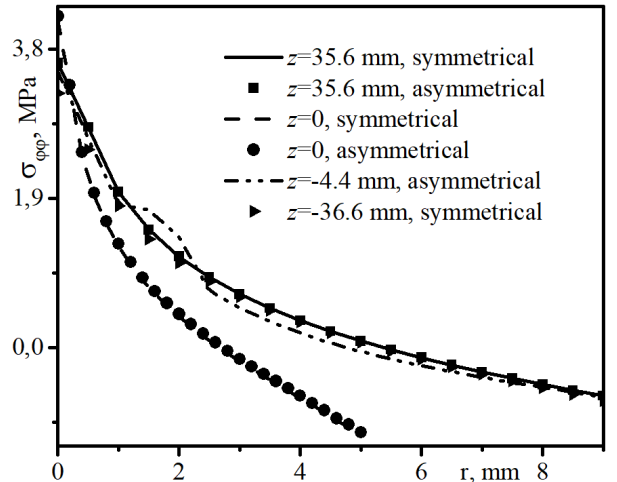

Figure 11. Comparison of stress changes $\sigma_{\varphi \varphi}$ for different $z$ of the fixed symmetric and asymmetric cylinder with the groove at $t=100 h$

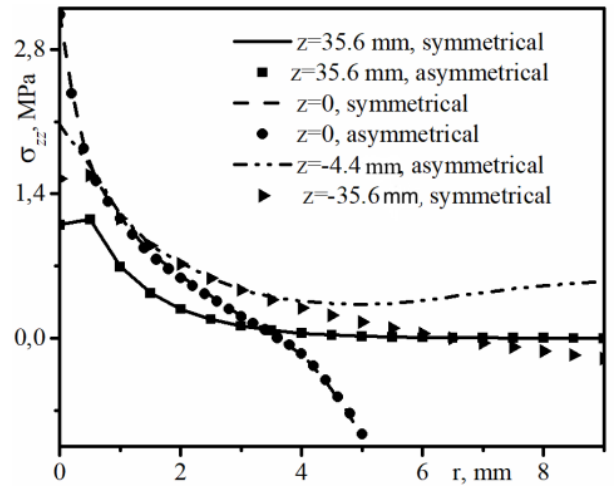

Figure 12. Comparison of stress changes $\sigma_{z z}$ for different $z$ of the fixed symmetric and asymmetric cylinder with the groove at $t=100 h$

Conclusions. The method of calculating the stresses in the body located in water environment is developed. These stresses are caused by changes in the hydrogen concentration. On the basis of the principle of virtual work for quasi-static equilibrium equations in predicting formulation at time $t+\Delta t$ the finite - elemental equation for determination the displacement growth at each time step is obtained. Knowing this displacement growth, you can get the stresses value. The resulting equation contains coefficients that depend on the deformation caused by the increase in hydrogen concentration over time $\Delta t$. Increase in hydrogen concentration over time $\Delta t$, and hence hydrogen deformations, are determined from Fick equation. In order to solve this equation with different boundary and initial conditions finite elemental equation is given. The use of the proposed method is demonstrated for determination of the stress state of the cylindrical samples during their dehydration or hydrogenation. These calculations were carried out using own computer program. Thus, while considering fixed and unfixed solid cylinders, it was found that the stress distribution $\sigma_{r r}$ та $\sigma_{\varphi \varphi}$ is almost identical and practically independent on $z$ value. On the contrary, the stress distribution $\sigma_{\mathrm{zz}}$ does not always coincide for fixed unfixed solid cylinders. The similar pattern is observed for stresses $\sigma_{r r}$ and $\sigma_{\varphi \varphi}$ (except for the groove area) and for cases of fixed and unfixed cylinders with the groove in the middle. The distribution of these stresses within the groove limits is substantially different from the distribution outside the groove. Sresses $\sigma_{\mathrm{zz}}$ above the groove coincide for both fixed and unfixed cylinders. Unlike the stresses $\sigma_{r r}$ in the groove area, the stresses $\sigma_{z z}$ and $\sigma_{\varphi \varphi}$ do not coincide these cylinders. If we consider the stresses distribution in symmetrical and asymmetrically fixed cylinders with the groove, then the stress distribution is almost the same. Only for $\sigma_{z z}$ it is different in the fixing area.

\section{References}

1. Glukhova Zh. L., Goltsov V. A., Schegoleva T. A. et al. Mathematical modeling of hydroelastic effect of slowing down of diffusion processes in metal-hydrogen system. Int. J. Nucl. Hydrogen Prod. App-2008. № 4. P. 334-342. https://doi.org/10.1504/IJNHPA.2008.023107

2. Goltsov V. A., Glukhova Zh. L., Lyubimenko E. N. et al. Vodorodnyje koncentracionnyje naprjazenija: priroda, eksperimentalnyje projavlenia, znachimost' dlja techniki. Metalurhija. 2009. Vyp. 11 (159). P. 165-173. [In Russian]. 
3. Staschuk M. H. Mutual influence of stress-strain state and hydrogen concentration in the metal-hydrogen system. Material Science. 2011. 47. № 4. P. 400-508. https://doi.org/10.1007/s11003-012-9421-1

4. Panasyuk V. V., Ivanyts'kyi Ya. L., Hembara O. V., Boiko V. M. Influence of the stress-strain state on the distribution of hydrogen concentration in the process zone system. Material Science. 2014. 50. № 3. P. 315323. https://doi.org/10.1007/s11003-014-9723-6

5. Krom A. H. M., Koers R. W. J., Bakker A. Hydrogen transport near a blunting crack tip. J. Mech. Phys. Solids.1999. 47. № 4. P. 971-992. https://doi.org/10.1016/S0022-5096(98)00064-7

6. Kanayama H., Shingoh T., S. Ndong-Mefane et al. Numerical analysis of hydrogen diffusion problems using the finite element method. J. Theoretical and Applied Mechanics Japan. 2008. 56. P. 389-400.

7. Staschuk M. H. Influence of hydrogen concentration on the stressesin a solid metallic cylinder. Material Science. 2017. 53. № 6. P. 824-830. https://doi.org/10.1007/s11003-018-0142-y

8. Hutton D. W. Fundamentals of finite element analysis. New York: McGraw-Hill, 2004. 494 p.

9. Filho O. J. A. G. Creep-rupture behavior of a cruciform specimen under equal triaxial tension. Int. J. Mech. Sci. 1992. 34. № 10. P. 769-783. https://doi.org/10.1016/0020-7403(92)90041-E

\section{Список використаної літератури}

1. Glukhova Zh. L., Goltsov V. A., Schegoleva T. A. et al. Mathematical modeling of hydroelastic effect of slowing down of diffusion processes in metal-hydrogen system. Int. J. Nucl. Hydrogen Prod. App-2008. № 4. P. 334-342. https://doi.org/10.1504/IJNHPA.2008.023107

2. Гольцов В. А., Глухова Ж. Л., Любименко Е. Н., Щеголева Т. А. Водородные концентрационные напряжения: природа, экспериментальные проявления, значимость для техники. Металургія. 2009. Вип. 11 (159). С. 165-173.

3. Стащук М. Г. Взаємовплив напружено-деформованого стану і концентрації водню в системі «метал-водень». Фіз.-хім. механіка матеріалів. 2011. 47. № 4. С. 71-77. https://doi.org/10.1007/ s11003-012-9421-1

4. Панасюк В. В., Іваницький Я. Л., Гембара О. В., Бойко В. М. Вплив напружено-деформованого стану на розподіл концентрації водню у зоні передруйнування. Фіз.-хім. механіка матеріалів. 2014. 50. № 3. C. 71-77. https://doi.org/10.1007/s11003-014-9723-6

5. Krom A. H. M., Koers R. W. J., Bakker A. Hydrogen transport near a blunting crack tip. J. Mech. Phys. Solids.1999. 47. № 4. P. 971-992. https://doi.org/10.1016/S0022-5096(98)00064-7

6. Kanayama H., Shingoh T., S. Ndong-Mefane et al. Numerical analysis of hydrogen diffusion problems using the finite element method. J. Theoretical and Applied Mechanics Japan. 2008. 56. P. 389-400.

7. Стащук М. Г. Вплив концентрації водню на напруження у суцільному металевому циліндрі. Фіз.-хім. механіка матеріалів. 2017. 53. № 6. С. 73-79. https://doi.org/10.1007/s11003-018-0142-y

8. Hutton D. W. Fundamentals of finite element analysis. New York: McGraw-Hill, 2004. 494 p.

9. Filho O. J. A. G. Creep-rupture behavior of a cruciform specimen under equal triaxial tension. Int. J. Mech. Sci. 1992. 34. № 10. P. 769-783. https://doi.org/10.1016/0020-7403(92)90041-E 


\title{
УДК 539.4
}

\section{ВИЗНАЧЕННЯ ВПЛИВУ КОНЦЕНТРАЦІЇ ВОДНЮ НА НАПРУЖЕННЯ У КОНСТРУКЦІЯХ}

\author{
Микола Стащук'; Василь Бойко'; Роман Гром'як² \\ ${ }^{1}$ Фізико-механічний інститут імені Г. В. Карпенка НАН Украӥни, \\ Львів, Україна \\ ${ }^{2}$ Тернопільський національний технічний університет імені Івана Пулюя, \\ Тернопіль, Україна
}

\begin{abstract}
Резюме. У переважній більшості експлуатація металевих конструкиій у робочих умовах призводить до того, щуо на изі конструкції або на певні їх елементи постійно діють не лите механічні фактори (навантаження, залишкові напруження ц̌ m. п.), але й навколишнє середовище. Елементи трубопроводів, несучі ділянки тепло- та гідроелектростаниій, металеві конструкиіі мостів протягом усього терміну експлуатаиії перебувають під впливом середовища, яке їх заповнює або оточує. Таке середовище, залежно від вмісту в ньому кислот та лугів, низки воденьвмісних середовищ, може виступати як корозійне. Слід також зауважити, щзо вплив корозійного середовища та дія механічних факторів є одночасні й взаємопов'язані між собою, щзо дуже часто призводить до крихкого чи квазікрихкого руйнування металу. Тому проблема оиінювання основних інженерних параметрів (міцності, надійності й m. п.) металевих конструкиій, які зазнають корозійного впливу при одночасній дї̈ механічних силових факторів, на даний момент є актуальною проблемою промислової експлуатації. Мало вивченими ще залишаються питання взаємовпливу водню та напружень у металоконструкціях. За наводнення металевого тіла змінюються лінійні розміри його елементів та об'єм. Водночас зміна об'єму тіла за певних умов викликає внутрішні напруження. Приймаємо, що взаємодія між атомами водню незначна. Потрібно встановити напружено-деформований стан металевого тіла зумовлений концентрацією водню у ньому. Також за дії зовнішніх навантажень у тілі виникають напруження $\sigma_{i k}(i, k=1,2,3)$. 3гідно з класичною теорією пружності напруження такого характеру зумовлюють відповідні видовження та зсуви. Тому напруження $\sigma_{i k}$ викликають деформації. За законом суперпозиції приріст повних деформацій дорівнює сумі деформацій, викликаних зміною концентрації водню, та деформацій, зумовлених напруженнями в тілі.
\end{abstract}

Ключові слова: напруження, деформаџії, концентрація водню, метод скінченних елементів, обернений метод Ейлера, принциип віртуальної роботи, ичиліндричні зразки. 